\title{
PENGUKURAN KUALITAS LAYANAN DI UNIVERSITAS KRISTEN INDONESIA (UKI)
}

\author{
Freddy Simbolon \\ Management Department, School of Business and Management, BINUS Unversity \\ Jln. KH. Syahdan No. 9, Kemanggisan-Palmerah, Jakarta 11480
}

\begin{abstract}
The purpose of this study was to determine the service quality that was held by UKI based on student's perceptions. The method used in this study is the survey method on UKI's students using questionnaires. The statement in the questionnaires were arrange based on the five dimensions of service quality. Those were tangibles, responbilities, assurances, realibilities, and emphathy. The servqual analysis shows that all attributes get a negative response which means that student's perception is less than the student's expectations. The IPM shows attributes that need to get first priority to be improved are library facilities more complete, lecturing process more interactive, handling complaints about the lectures properly, the tuition in accordance with benefits, and the librarian serve students with friendly.
\end{abstract}

Keywords: service quality, SERVQUAL/gap analysis, Importance Performance Analysis

\begin{abstract}
ABSTRAK
Penelitian ini bertujuan untuk mengetahui kualitas layanan yang diselenggarakan oleh UKI berdasarkan persepsi mahasiswa. Metode penelitian yang digunakan adalah metode survei dengan menggunakan kuesioner. Pernyataan dalam kuesioner disusun berdasarkan lima dimensi kualitas layanan yang meliputi tangibles, responbilities, assurances, realibilities, dan emphathy. Berdasarkan analisis gap menunjukkan bahwa semua atribut layanan bernilai negatif yang berarti persepsi kinerja layanan lebih kecil dari harapan mahasiwa. Adapun berdasarkan analisis IPM diketahui atribut yang menjadi prioritas untuk ditingkatkan kinerjanya adalah fasilitas perpustakaan yang lengkap, proses kuliah berlangsung lebih interaktif, keluhan mengenai perkuliahan ditanggapi dengan baik, biaya kuliah sesuai dengan manfaat perkuliahan, serta petugas perpustakaan melayani dengan ramah.
\end{abstract}

Kata kunci: kualitas layanan, analisis Servqual/gap, Importance Performance Analysis 


\section{PENDAHULUAN}

Salah satu tuntutan dalam era globalisasi adalah sumber daya manusia yang berkualitas. Peningkatan kualitas sumberdaya manusia seyogyanya menjadi salah satu fokus utama dalam sistem pendidikan nasional, terutama yang berkaitan dengan penyelenggaraan proses pendidikan oleh lembaga pendidikan, khususnya perguruan tinggi (Furqon, 2007:373). Lulusan perguruan tinggi yang berkualitas memiliki implikasi pada terciptanya keunggulan kompetitif secara nasional. Idealnya, tujuan pendidikan nasional adalah untuk mencerdaskan manusia Indonesia dan mengembangkan manusia Indonesia seutuhnya. Perguruan tinggi sebagai penyelenggara pendidikan tentunya harus menyelaraskan dengan tujuan pendidikan nasional tersebut yang secara implisit menekankan pada pentingnya kualitas sumber daya manusia yang dihasilkan selain aspek pemerataan pendidikan, dan aspek-aspek lainnya. Sebagai konsekuensinya perguruan tinggi dituntut memiliki kualitas yang memadai pula, sesuai dengan perkembangan kondisi yang ada.

Pertumbuhan pendidikan tinggi tersebut mendorong timbulnya persaingan dalam menawarkan layanan yang dinilai menarik, seperti fasilitas pendukung, kompetensi pengajar dan staf pendukung, dan sebagainya. Komitmen dalam memberikan layanan yang berkualitas sebagai salah satu prasyarat keberhasilan sebuah usaha. Layanan berkualitas berarti memberikan layanan sesuai dengan kebutuhan konsumen. Hal tersebut juga berlaku bagi perguruan tinggi sebagai salah satu industri layanan. Dengan demikian kemampuan untuk mengetahui dan mengenali kebutuhan konsumen menjadi hal yang penting bagi penyedia layanan. Seperti yang dikemukakan oleh Tjiptono (2005:259) bahwa definisi kualitas layanan berfokus pada upaya pemenuhan kebutuhan dan keinginan konsumen serta ketepatan penyampaiannya untuk mengimbangi harapan konsumen, dalam hal ini mahasiswa.

Mengukur kualitas layanan menjadi hal penting bagi penyelenggara pendidikan tinggi. Hal ini dilakukan untuk mengetahui persepsi mahasiswa terhadap kinerja perguruan tinggi. Kualitas layanan menekankan pada kepuasan mahasiswa sebagai hal yang perlu menjadi perhatian penyelenggara pendidikan. Hal tersebut ditujuan untuk dapat menarik mahasiswa, melayani kebutuhan mahasiswa, serta mempertahankannya. Layanan disebut berkualitas apabila layanan yang diterima sesuai dengan layanan yang diharapkan. Adanya timbal balik dari penerima layanan menjadi cara efektif untuk mengetahui kualitas layanan penyelenggara pendidikan tinggi yang harus dipertahankan maupun ditingkatkan dalam rangka memajukan institusi yang bersangkutan. Diharapkan melalui penilaian tersebut, pihak penyelenggara pendidikan tinggi dapat meningkatkan kualitas layanannya dengan segera dan secara efektif.

Sebagai salah satu perguruan tinggi yang ada di Jakarta, Universitas Kristen Indonesia (UKI) telah berdiri sejak tahun 1953 yang terdiri dari dua fakultas, yaitu Fakultas Sastra dan Filsafat dan Fakultas Ekonomi (www.uki.ac.id). Dalam perkembangan selanjutnya terdapat penambahan Fakultas Hukum (1956), Fakultas Kedokteran (1962), Fakultas Teknik (1963), dan Fakultas Ilmu Sosial dan Politik (1994). Bahkan, Fakultas Kedokteran UKI merupakan Fakultas kedokteran swasta pertama di Indonesia. Sistem pendidikan UKI terdiri dari beberapa tingkatan yaitu diploma, sarjana, serta pasca sarjana. Prestasi yang telah dicapai UKI antara lain pada sebagai peringkat 6 perguruan tinggi swasta di Indonesia dan peringkat 18 untuk keseluruhan perguruan tinggi di Indonesia menurut penilaian Majalah Tempo tahun 2007 atas dasar Job Market Survey.

Penelitian ini bertujuan untuk mengetahui kualitas layanan yang diselenggarakan oleh UKI berdasarkan penilaian mahasiswa sebagai penerima layanan. Penilaian yang diberikan meliputi kinerja atribut layanan UKI yang dirasakan mahasiswa, harapan mahasiswa terhadap atribut layanan serta tingkat kepentingan atribut layanan tersebut. Diharapkan melalui penelitian ini dapat memberi masukan kepada pihak manajemen UKI mengenai atribut layanan yang harus dipertahankan maupun atribut layanan yang harus ditingkatkan kinerjanya. 


\section{Teori Singkat}

Kotler dan Keller (2012:153) mendefinisikan kualitas layanan adalah totalitas fitur dan karakteristik produk atau layanan yang mampu memuaskan kebutuhan konsumen yang dinyatakan atau tersirat. Adapun Wyckof dalam Tjiptono (2005:260) mengemukakan kualitas layanan adalah tingkat keunggulan yang diharapkan dan pengendalian atas tingkat keunggulan tersebut untuk memenuhi keinginan pelanggan. Dengan kata lain, terdapat dua faktor yang mempengaruhi kualitas layanan, yakni expected service/layanan yang diharapkan dan perceived service/layanan yang diterima. Kualitas harus dimulai dari kebutuhan pelanggan dan berakhir pada dengan kepuasan pelanggan serta persepsi positif terhadap kualitas jasa (Kotler dalam Tjiptono dan Chandra, 2011:180). Perusahaan yang berhasil menambahkan manfaat pada penawaran layanannya maka pelanggan tidak hanya puas, tetapi juga merasa diberi kejutan dan sangat puas (Rust dan Oliver dalam Kotler dan Keller, 2012:395).

Zeithaml, Bitner, dan Gremler (2008:75) mengemukakan ekspektasi konsumen adalah keyakinan terhadap penyampaian layanan sesuai standar atau acuan terhadap kinerja yang dinilai. Konsumen membandingkan persepsi terhadap kinerja dengan acuan tersebut pada saat menilai kualitas layanan, sehingga pemahaman mengenai harapan konsumen sebagai hal yang kritis bagi pemasar jasa. Konsumen membentuk ekspektasi terhadap jasa dari beberapa sumber seperti pengalaman masa lalu, informasi dari mulut ke mulut, dan iklan (Voss et al. dalam Kotler dan Keller, 2012:395). Adalah wajar jika pelanggan akan menentukan pilihan suatu jasa berdasarkan informasi dan membandingkan kualitas layanan yang dirasakan dengan kualitas yang diharapkan. Implikasinya ialah ketika kualitas layanan dirasakan memenuhi atau lebih baik dari kualitas layanan yang diharapkan, maka mereka akan menggunakan layanan tersebut. Selanjutnya Zeithaml, Bitner dan Gremler (2008:32) mengemukakan definisi persepsi konsumen (customer perception) sebagai penilaian subyektif tentang pengalaman jasa yang sebenarnya.

Model kualitas layanan pada Gambar 1 berikut menggambarkan lima kesenjangan atau gap dalam memberikan suatu layanan, yaitu: (i) kesenjangan antara harapan konsumen dan persepsi manajemen (Gap 1); Hal ini disebabkan persepsi manajemen tidak selalu tepat merasakan layanan yang diinginkan atau diharapkan konsumen. (ii) Kesenjangan antara persepsi manajemen dengan spesifikasi kualitas layanan (Gap 2); dalam hal ini manajemen mungkin dapat merasakan keinginan atau harapan konsumen, tetapi bukan spesifikasi yang standar. (iii) Kesenjangan antara spesifikasi kualitas jasa dan penyampaian layanan (Gap 3); kesenjangan ini karena ketidaksesuaian kinerja pelayanan karena karyawan mungkin kurang dilatih atau tidak mampu memenuhi standar layanan sesuai yang diinginkan konsumen, misalnya waktu untuk mendengarkan konsumen dan melayani konsumen dengan cepat. (iv) Kesenjangan antara penyampaian jasa dan komunikasi eksternal (Gap 4); harapan konsumen dipengaruhi oleh pernyataan perwakilan perusahaan dan iklan selanjutnya terdapat ketidaksesuaian layanan yang dijanjikan dengan layanan yang disampaikan. (v) Kesenjangan antara layanan yang dialami dengan layanan yang diharapkan (Gap 5); kesenjangan tersebut karena konsumen tidak merasakan kualitas layanan sesuai yang diharapkan. 


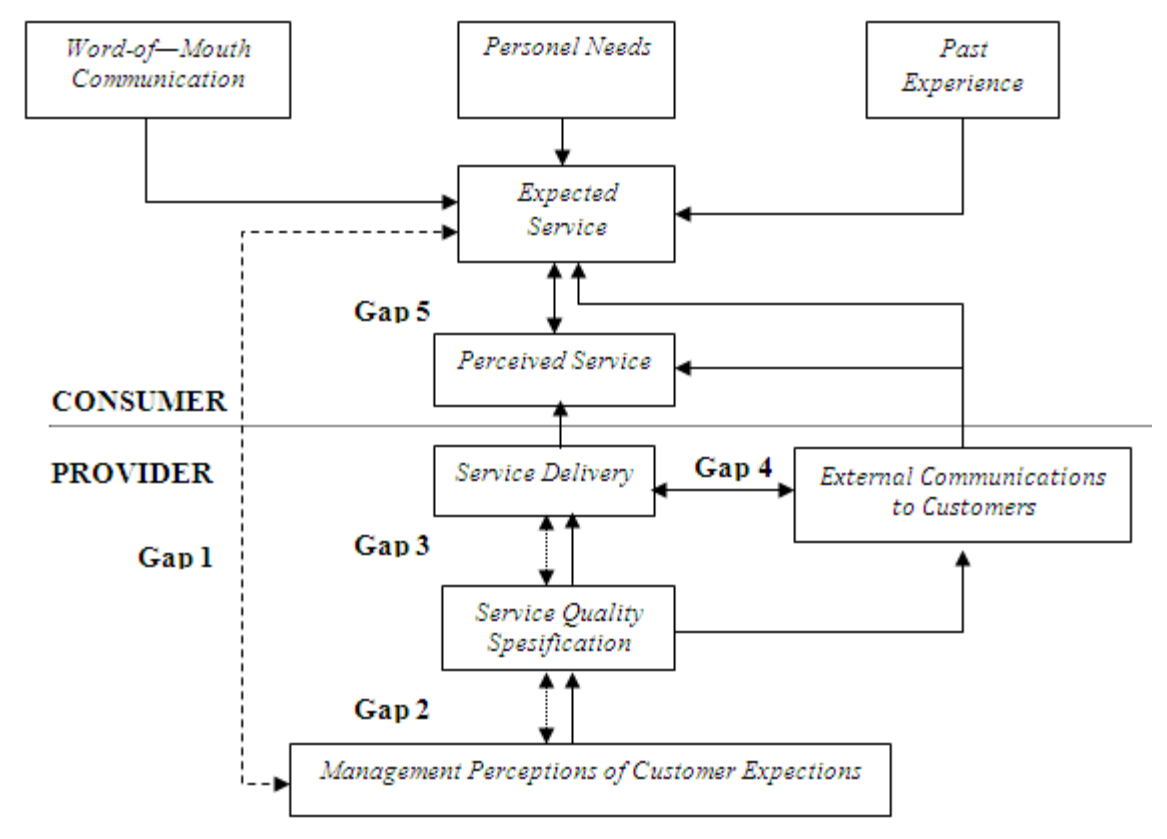

Gambar 1 Service-Quality Model

Sumber : A. Parasuraman, V.A. Zeithaml, dan L.L. Berry dalam Kotler dan Keller (2012:395)

Dimensi kualitas layanan menurut Zeithaml et al. dalam Mullins dan Walker (2010:445) adalah: berwujud (tangible), merupakan penampilan sarana fisik, perlengkapan, karyawan, serta sarana komunikasi; kehandalan (reliability), adalah kemampuan untuk memberikan layanan sesuai dengan yang dijanjikan secara tepat dan terpercaya; daya tanggap (responsiveness), merupakan kemauan untuk membantu pelanggan dan memberikan pelayanan dengan tepat; jaminan (assurance), yaitu pengetahuan dan keramahan pegawai serta kemampuan untuk bisa menjaga kepercayaan dan rahasia; empati (emphaty), kesediaan untuk peduli, memberi perhatian kepada pelanggan secara individual.

Model Servqual menganalisis gap antara dua variabel pokok, yaitu layanan yang diharapkan (expected service) dan layanan yang dipersepsikan (perceived service). Selanjutnya Zeithaml et al. dalam Tjiptono dan Chandra (2011:231-232) mengemukakan bahwa pengukuran kualitas jasa dalam Model Servqual didasarkan pada skala multi item yang dirancang untuk mengukur harapan dan persepsi pelanggan, serta gap diantara keduanya pada lima dimensi utama kualitas jasa. Kelima dimensi utama dijabarkan kedalam atribut untuk variabel harapan dan variabel persepsi yang disusun dalam pernyataan-pernyataan berdasarkan skala Likert dari 1 (sangat tidak setuju) sampai 7 (sangat setuju). Evaluasi kualitas jasa menggunakan Model Servqual mencakup perhitungan perbedaan diantara nilai yang diberikan konsumen untuk setiap pasang pernyataan berkaitan dengan harapan dan persepsi. Skor Servqual dapat dihitung berdasarkan rumus sebagai berikut:

\section{Gap $=$ Persepsi - Harapan}

Penilaian layanan dapat didasarkan pada kepentingan konsumen dengan kinerja perusahaan/penyedia layanan. Importance - Performance Analysis (IPA) menilai layanan dengan mengidentifikasi tindakan diperlukan (Martilla dan James dalam Kotler dan Keller, 2012:389). Penilaian IPA didasarkan tingkat kepentingan dari kualitas layanan (importance) dengan kinerja kualitas layanan (performance). Selanjutnya nilai kepentingan konsumen dan kinerja layanan diratarata untuk diplot pada diagram kartesius dengan kinerja (performance) berlaku sebagai sumbu mendatar dan tingkat kepentingan (importance) sebagai sumbu vertikal. Diagram kartesius tersebut 
terbagi menjadi empat kuadran, dengan penjabaran sebagai berikut: Kuadran A (Concentrate Here) menunjukkan atribut layanan yang penting tetapi kinerjanya tidak seperti yang diharapkan; Kuadran B (Keep Up The Good Work) terdiri dari atribut layanan yang penting dengan kinerja yang baik, dengan demikian perusahaan perlu untuk mempertahankan kinerja atribut tersebut; Kuadran C (Low Priority) menunjukkan atribut yang disampaikan secara biasa saja sehingga tidak perlu perhatian; dan Kuadran D (Possible Overkill) terdiri dari atribut yang dianggap kurang penting tetapi kinerjanya dilakukan dengan sangat baik. Matriks Importance -Performance tersaji pada Gambar 2 berikut ini.

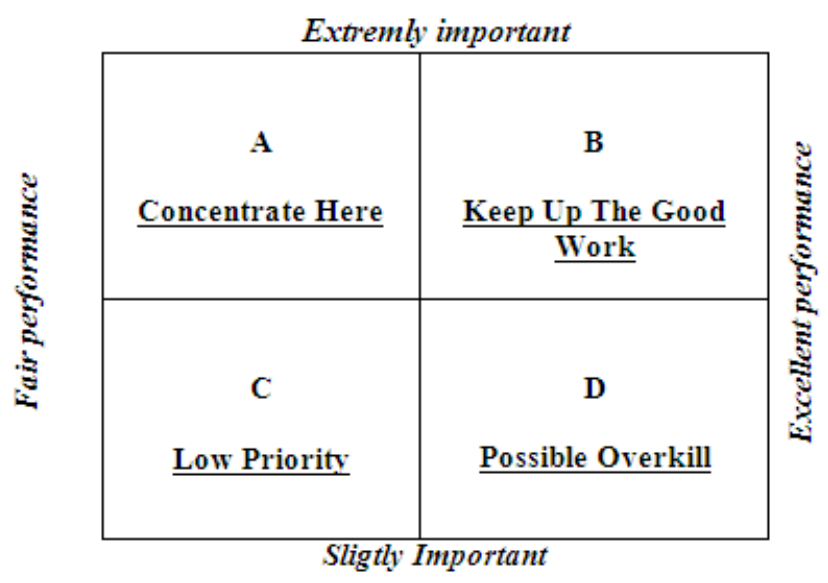

Gambar 2 Importance Performance Analysis

Penelitian ini mengacu pada penelitian yang dilakukan sebelumnya yaitu Devi Damajanti (2006) mengenai 'Pengukuran Kualitas Pelayanan di Apotik Trijaya' dan Asmiardi Muluk (2008) tentang 'Analisis Kualitas Pelayanan Jasa Perbankan'. Kedua penelitian tersebut menggunakan analisis Servqual berdasarkan lima dimensi layanan yaitu dimensi bukti fisik (tangible), reliabilitas (realibility), daya tanggap (responsiveness), empati (empathy), dan jaminan (assurance). Atributatribut dalam kelima dimensi dilakukan penilaian terhadap kinerja atribut serta harapan nasabah atau konsumen terhadap atribut tersebut. Untuk mengetahui prioritas atribut yang harus ditingkatkan, kedua penelitian tersebut menggunakan analisis IPM.

Hasil penelitian yang dilakukan Devi Damajanti menunjukkan bahwa semua atribut layanan mendapat nilai negatif, dimana kenyataan kinerja atribut layanan belum sesuai dengan harapan konsumen. Kesenjangan terbesar layanan apotik adalah ruang tunggu yang nyaman dan bersih. Adapun berdasarkan analisis IPM, atribut yang harus ditingkatkan adalah ruag tunggu nyaman dan bersih, memberi pelayanan dengan benar sejak awal, memberi pelayanan tepat waktu sesuai yang dijanjikan, pelayanan dengan segera/cepat dari karyawan apotik, karyawan memiliki sifat yang jujur dan dapat dipercaya, karyawan memiliki pengetahuan yang dibutuhkan dalam melayani anda, dan mudah diubungi melalui telepon. Pada penelitian Asmiardi Muluk (2008) menunjukkan adanya kesenjangan untuk semua dimensi layanan. Kesenjangan terbesar adalah untuk dimensi jaminan (assurance) dan dimensi daya tanggap (responsiveness). Berdasarkan hasil analisis IPM, atribut yang harus ditingkatkan kinerjanya adalah atribut memberikan layanan dengan baik dan teliti, kemampuan karyawan dalam menepati layanan yang dijanjikan, kemampuan karyawan dalam menyelesaikan pelayanan dengan tuntas, serta ketersediaan fasilitas kursi tunggu pada area pelayanan. 


\section{METODE PENELITIAN}

Jenis penelitian ini merupakan penelitian survei untuk mengetahui kualitas layanan UKI dengan menggunakan metode servqual. Menurut Sugiyono (2004:72) populasi adalah wilayah generalisasi yang terdiri atas obyek atau subyek yang mempunyai kualitas dan karakteristik tertentu yang ditetapkan oleh peneliti untuk dipelajari dan kemudian diambil kesimpulannya. Sampel adalah sebagian dari jumlah dan karakteristik yang dimilki oleh populasi tersebut. Populasi penelitian ini adalah mahasiswa UKI program Sarjana (S1). Adapun responden penelitian adalah sampel sebagai bagian dari jumlah dan karakteristik yang memiliki oleh populasi tertentu. Responden penelitian terdiri dari mahasiswa Fakultas Kedokteran, Fakultas Teknik, dan Fakultas Ekonomi secara keseluruhan berjumlah 103 mahasiswa dengan teknik pengambilan sampel secara non probability sampling.

Metode pengumpulan data dilakukan dengan wawancara melalui kuesioner terstruktur terhadap responden. Dalam kuesioner dikembangkan 21 buah pernyataan kualitas layanan sebuah universitas berdasarkan lima dimensi kualitas layanan/servqual. Selanjutnya responden menilai pernyataan kualitas layanan berkaitan dengan persepsi kinerja layanan UKI yang dirasakan, harapan responden terhadap layanan suatu universitas, dan tingkat kepentingan layanan. Penilaian yang diberikan menggunakan skala likert. Menurut Sekaran (2006:31) skala likert didesain untuk menelaah seberapa kuat subyek setuju atau tidak setuju dengan pernyataan. Dengan skala likert, variabel yang diukur digunakan untuk menyusun pernyataan. Jawaban setiap pernyataan yang menggunakan skala likert mempunyai gradasi dari sangat positif sampai sangat negatif adalah sebagai berikut : $7=$ Sangat Setuju (SS), 6 = Setuju (S), 5 = Agak Setuju (AS), $4=$ Netral (N), $3=$ Agak Tidak Setuju (ATS), $2=$ Tidak Setuju (TS), dan 1 = Sangat Tidak Setuju (STS). Sama halnya seperti penilaian tingkat kepentingan, juga menggunakan skala 1 sampai dengan 7 dengan kata-kata sebagai berikut : $1=$ Sangat Tidak Penting (STP); $2=$ Tidak Penting (TP); $3=$ Agak Tidak Penting (ATP); $4=\operatorname{Netral~(N);~} 5$ $=$ Agak Penting (AP) ; $6=$ Penting (P); dan 7= Sangat Penting (SP). Adapun pernyataan kualitas layanan dalam penelitian ditampilkan pada Tabel 1.

\section{Analisis Deskriptif}

Dalam analisis ini ditampilkan profil responden meliputi fakultas, semester perkuliahan, dan usia dalam bentuk tabel. Demikian pula dengan penilaian responden terhadap pernyataan kualitas layanan yang meliputi harapan, persepsi terhadap kinerja, dan tingkat kepentingan juga disajikan dalam bentuk tabulasi frekuensi berdasarkan kategori penilaiannya.

\section{Analisis Gap}

Pengukuran kualitas layanan dalam Model Servqual didasarkan pada skala yang dirancang untuk mengukur harapan dan persepsi responden terhadap kinerja layanan serta gap diantara keduanya dalam lima dimensi. Oliver dalam Tjiptono dan Chandra (2011:215) menyatakan bahwa Model Servqual dikenal pula dengan istilah Gap Analysis. Dalam penelitian ini yang diukur adalah gap 5 (berdasarkan Gambar 1). Analisis gap dalam metode Servqual dihitung seperti rumus berikut:

\section{Gap = Nilai Persepsi - Nilai Harapan}

Apabila gap bernilai positif, maka tidak terdapat kesenjangan antara persepsi kinerja dengan harapan sehingga nasabah merasa puas. Sebaliknya gap bernilai negatif, menunjukkan adanya harapan responden belum terpenuhi dengan kinerja saat ini. 
Tabel 1 Pernyataan Penelitian Berdasarkan Lima Dimensi Kualitas Layanan

\begin{tabular}{|c|c|}
\hline Dimensi & Pernyataan \\
\hline Bukti Fisik/Tangible & $\begin{array}{l}\text { 1. Ruang kuliah nyaman dan tenang } \\
\text { 2. Lokasi kampus strategis atau mudah dijangkau } \\
\text { 3. Universitas memiliki ketersediaan jurusan atau program studi } \\
\text { 4. Penampilan dosen selalu rapi } \\
\text { 5. Fasilitas pendukung perkuliahan seperti laboratorium, kantin, parkir, } \\
\text { tempat ibadah dll } \\
\text { 6. Fasilitas perpustakaan yang lengkap }\end{array}$ \\
\hline Daya Tanggap/ Responsiveness & $\begin{array}{l}\text { 1. Pelayanan administrasi kepada mahasiswa dilakukan dengan cepat } \\
\text { 2. Proses perkuliahan berlangsung secara interaktif } \\
\text { 3. Keluhan mengenai perkuliahan ditanggapi dengan baik }\end{array}$ \\
\hline Jaminan/Assurance & $\begin{array}{l}\text { 1. Staf administrasi melayani mahasiswa dengan ramah } \\
\text { 2. Dosen mampu menjelaskan materi kuliah dengan baik } \\
\text { 3. Cara penyampaian materi kuliah dapat menarik mahasiswa }\end{array}$ \\
\hline Kehandalan/Realibility & $\begin{array}{l}\text { 1. Kehadiran dosen dalam proses perkuliahan tepat waktu } \\
\text { 2. Materi kuliah sesuai dengan silabus } \\
\text { 3. Materi kuliah sesuai degan jurusan yang diambil atau dipilih } \\
\text { 4. Durasi/lama proses kuliah sesuai dengan jurusan yang diambil } \\
\text { 5. Biaya kuliah sesuai dengan manfaat perkuliahan } \\
\text { 6. Nilai mata kuliah ditentukan secara transparans }\end{array}$ \\
\hline Empati / Emphathy & $\begin{array}{l}\text { 1. Dosen memberikan perhatian secara personal kepada mahasiswa } \\
\text { 2. Dosen bersedia berdiskusi dengan mahasiswa, baik didalam maupun } \\
\text { diluar jam kuliah } \\
\text { 3. Petugas perpustakaan melayani dengan ramah }\end{array}$ \\
\hline
\end{tabular}

\section{Analisis IPA/Kuadran}

Analisis IPA digunakan untuk mengukur atribut berdasarkan tingkat kepentingan dengan kepuasan terhadap kinerja. Hasil penilaian responden tersebut selanjutnya diplot pada diagram kartesius dengan tingkat kinerja berlaku sebagai sumbu mendatar dan tingkat kepentingan sebagai sumbu vertikal. Dari data hasil penilaian atribut-atribut layanan dalam kuesioner dihitung rata-rata (mean) dengan rumus sebagai berikut:

$$
\begin{aligned}
& \bar{X}=\sum_{\mathrm{n}}^{\sum \mathrm{X}_{\mathrm{i}}} \quad \begin{array}{c}
\mathrm{X}=\text { nilai rata-rata tingkat kinerja } \\
\mathrm{n}=\text { jumlah responden }
\end{array} \\
& \overline{\mathrm{Y}}=\frac{\sum \mathrm{Y}_{\mathrm{i}}}{\mathrm{n}} \quad \mathrm{Y}=\text { nilai rata-rata tingkat kinerja }
\end{aligned}
$$

Selanjutnya dalam diagram kartesius IPA ditentukan titik potong antara dua garis yang saling tegak lurus sebagai rataan dari rata-rata skor kinerja dan rataan dari rata-rata skor tingkat kepentingan.

\section{HASIL DAN PEMBAHASAN}

\section{Profil Responden}

Pada Tabel 2 berikut ditampilkan profil mahasiswa yang responden dalam penelitian yang meliputi fakultas, semester perkuliahan, dan usia. 
Tabel 2 Profil Responden Penelitian

\begin{tabular}{|c|c|c|}
\hline Profil Responden & Jumlah (orang) & Persen \\
\hline \multicolumn{3}{|l|}{ Fakultas } \\
\hline 1. Ekonomi & 26 & $25,2 \%$ \\
\hline 2. Kedokteran & 42 & $40,8 \%$ \\
\hline 3. Teknik & 35 & $34,0 \%$ \\
\hline \multicolumn{3}{|l|}{ Semester } \\
\hline 1. 2 & 58 & $56,3 \%$ \\
\hline 2. & 24 & $23,3 \%$ \\
\hline 3. & 17 & $16,5 \%$ \\
\hline 4. 8 & 4 & $3,9 \%$ \\
\hline \multicolumn{3}{|l|}{ Usia } \\
\hline 1. $17-20$ tahun & 51 & $49,5 \%$ \\
\hline 2. $21-24$ tahun & 44 & $42,7 \%$ \\
\hline 3. $25-28$ tahun & 8 & $7,8 \%$ \\
\hline
\end{tabular}

Responden terdiri dari mahasiswa Fakultas Kedokteran yaitu sebesar 40,8 \% yang diikuti oleh mahasiswa Fakultas Teknik (34 \%) dan mahasiswa Fakultas Ekonomi (25,2 \%). Berdasarkan semester perkuliahan, saat ini sebagian besar responden merupakan mahasiswa semester 2 yaitu sebesar 56,3\% dan lainnya merupakan mahasiswa semester 4, 6, dan 8. Adapun usia responden penelitian dibagi menjadi kategori 17-20 tahun, 21-24 tahun, dan 25-28 tahun. Kategori usia sebagian besar responden adalah 17-20 tahun dengan persentase 49,5\%.

\section{Penilaian Harapan Responden terhadap Layanan Universitas}

Mahasiswa memiliki harapan sebelum menerima layanan suatu universitas, sebagai keinginan atau kebutuhan terhadap layanan tersebut. Tiap individu memiliki tingkatan harapan yang berbeda, seperti halnya harapan mahasiswa terhadap pernyataan kualitas layanan dalam penelitian. Tabel 3 berikut menyajikan harapan responden terhadap kualitas layanan suatu universitas disertai dengan jumlah responden berdasarkan kategori penilaiannya.

Tabel 3 Harapan Responden terhadap Kualitas Layanan Universitas

\begin{tabular}{|c|c|c|c|c|c|c|c|c|}
\hline No. & Pernyataan & STS & TS & ATS & $\mathbf{N}$ & AS & $\mathbf{S}$ & SS \\
\hline & Dimensi Bukti Fisik /Tangibles & & & & & & & \\
\hline 1 & Ruang kuliah nyaman dan tenang & 1 & 0 & 0 & 0 & 0 & 44 & 58 \\
\hline 2 & Lokasi kampus strategis / mudah dijangkau & 1 & 0 & 0 & 2 & 1 & 51 & 48 \\
\hline 3 & Universitas memiliki ketersediaan jurusan atau program studi & 1 & 0 & 0 & 3 & 7 & 53 & 39 \\
\hline 4 & Penampilan dosen selalu rapi & 1 & 0 & 0 & 4 & 14 & 50 & 34 \\
\hline 5 & $\begin{array}{l}\text { Fasilitas pendukung perkuliahan, seperti laboratorium, kantin, parkir, tempat } \\
\text { ibadah, dll }\end{array}$ & 0 & 1 & 0 & 2 & 9 & 37 & 54 \\
\hline 6 & Fasilitas perpustakaan yang lengkap & 1 & 0 & 0 & 3 & 10 & 39 & 50 \\
\hline & Dimensi Daya Tanggap/Responsiveness & & & & & & & \\
\hline 7 & Pelayanan administrasi kepada mahasiswa dilakukan dengan cepat & 0 & 1 & 1 & 5 & 11 & 38 & 47 \\
\hline 8 & Proses perkuliahan berlangsung secara interaktif & 1 & 0 & 0 & 5 & 7 & 45 & 45 \\
\hline 9 & Keluhan mengenai perkuliahan ditanggapi dengan baik & 1 & 0 & 1 & 2 & 6 & 45 & 48 \\
\hline & Dimensi Jaminan/Assurances & & & & & & & \\
\hline 10 & Staf administrasi melayani mahasiswa dengan ramah & 0 & 3 & 0 & 6 & 11 & 46 & 37 \\
\hline 11 & Dosen mampu menjelaskan materi kuliah dengan baik & 1 & 0 & 0 & 3 & 3 & 36 & 60 \\
\hline 12 & $\begin{array}{l}\text { Cara penyampaian materi kuliah dapat perhatian mahasiswa } \\
\text { Dimensi Kehandalan/Realibilities }\end{array}$ & 1 & 0 & 0 & 4 & 4 & 32 & 62 \\
\hline 13 & Kehadiran dosen dalam proses perkuliahan tepat waktu & 1 & 0 & 0 & 3 & 13 & 46 & 40 \\
\hline 14 & Materi kuliah sesuai dengan silabus & 1 & 0 & 0 & 3 & 15 & 63 & 21 \\
\hline 15 & Materi kuliah sesuai dengan jurusan yang diambil atau dipilih & 1 & 0 & 0 & 3 & 8 & 60 & 31 \\
\hline 16 & Durasi/lama proses kuliah tepat waktu & 1 & 0 & 0 & 7 & 17 & 52 & 26 \\
\hline 17 & Biaya kuliah sesuai dengan manfaat perkuliahan & 1 & 0 & 0 & 4 & 4 & 45 & 49 \\
\hline 18 & $\begin{array}{l}\text { Nilai mata kuliah ditentukan secara tranparans } \\
\text { Dimensi Empati/Emphaty }\end{array}$ & 1 & 0 & 0 & 6 & 4 & 44 & 48 \\
\hline 19 & Dosen memberikan perhatian secara personal kepada mahasiswa & 2 & 0 & 1 & 17 & 23 & 44 & 16 \\
\hline 20 & $\begin{array}{l}\text { Dosen bersedia berdiskusi dengan mahasiswa, baik di dalam maupun diluar jam } \\
\text { kuliah }\end{array}$ & 1 & 0 & 0 & 3 & 15 & 46 & 38 \\
\hline 21 & Petugas perpustakaan melayani dengan ramah & 0 & 1 & 0 & 4 & 11 & 45 & 42 \\
\hline
\end{tabular}

Keterangan : STS = Sangat Tidak Setuju; TS = Tidak Setuju; ATS = Agak Tidak Setuju; N = Netral; AS = Agak Setuju; $\mathrm{S}=$ Setuju; SS = Sangat Setuju. 
Harapan responden terhadap tiap pernyataan kualitas layanan universitas, sebagian besar responden menyatakan setuju (S) dan sangat setuju (SS). Berdasarkan Tabel 3 terlihat bahwa mayoritas responden menilai Sangat Setuju (SS) pada pernyataan kualitas layanan universitas sebagai berikut: Ruang kuliah nyaman dan tenang (dimensi bukti fisik); Fasilitas pendukung perkuliahan, seperti laboratorium, kantin, parkir, tempat ibadah, dll (dimensi bukti fisik), fasilitas perpustakaan yang lengkap (dimensi bukti fisik); pelayanan administrasi kepada mahasiswa dilakukan dengan cepat (dimensi daya tanggap); keluhan mengenai perkuliahan ditanggapi dengan baik (dimensi daya tanggap); dosen-dosen mampu menjelaskan materi kuliah dengan baik (dimensi jaminan); cara penyampaian materi kuliah dapat menarik perhatian mahasiswa (dimensi jaminan); biaya kuliah sesuai dengan manfaat perkuliahan (dimensi kehandalan); nilai mata kuliah ditentukan secara tranparans (dimensi kehandalan). Adapun untuk pernyataan kualitas layanan suatu universitas lainnya, sebagian besar responden menyatakan Setuju, termasuk semua pernyataan yang tergolong dalam dimensi empati.

\section{Persepsi Responden terhadap Kinerja Layanan UKI}

Persepsi responden terhadap kinerja layanan merupakan penilaian subyektif responden terhadap pengalaman aktual dalam menerima layanan UKI. Penilaian persepsi responden terhadap kinerja kualitas layanan UKI tersaji pada Tabel 4 berikut.

Tabel 4 Persepsi Responden terhadap Kinerja Kualitas Layanan UKI

\begin{tabular}{|c|c|c|c|c|c|c|c|c|}
\hline No & Pernyataan & STS & TS & ATS & $\mathbf{N}$ & AS & $\mathbf{S}$ & SS \\
\hline & Dimensi Bukti Fisik/Tangibles & & & & & & & \\
\hline 1 & Ruang kuliah UKI nyaman dan tenang & 2 & 1 & 4 & 8 & 30 & 51 & 7 \\
\hline 2 & Lokasi kampus UKI strategis atau mudah dijangkau & 1 & 1 & 0 & 7 & 24 & 46 & 24 \\
\hline 3 & UKI memiliki ketersediaan jurusan atau program studi & 1 & 1 & 3 & 10 & 34 & 47 & 7 \\
\hline 4 & Penampilan dosen UKI selalu rapi & 1 & 0 & 2 & 10 & 32 & 47 & 11 \\
\hline 5 & $\begin{array}{l}\text { Fasilitas pendukung perkuliahan, seperti laboratorium, kantin, parkir, tempat } \\
\text { ibadah, dll }\end{array}$ & 2 & 0 & 2 & 17 & 23 & 44 & 15 \\
\hline 6 & Fasilitas perpustakaan UKI yang lengkap & 0 & 1 & 7 & 20 & 26 & 42 & 7 \\
\hline $\begin{array}{l}7 \\
8 \\
9\end{array}$ & $\begin{array}{l}\text { Dimensi Daya Tanggap/Responsiveness } \\
\text { Pelayanan administrasi UKI kepada mahasiswa dilakukan dengan cepat } \\
\text { Proses perkuliahan di UKI berlangsung secara interaktif } \\
\text { Keluhan mengenai perkuliahan di UKI ditanggapi dengan baik }\end{array}$ & $\begin{array}{l}2 \\
2 \\
4\end{array}$ & $\begin{array}{l}7 \\
0 \\
2\end{array}$ & $\begin{array}{l}14 \\
3 \\
6\end{array}$ & $\begin{array}{l}19 \\
19 \\
22\end{array}$ & $\begin{array}{l}27 \\
33 \\
32\end{array}$ & $\begin{array}{l}29 \\
42 \\
32\end{array}$ & $\begin{array}{l}5 \\
4 \\
5\end{array}$ \\
\hline $\begin{array}{l}10 \\
11 \\
12\end{array}$ & $\begin{array}{l}\text { Dimensi Jaminan/Assurance } \\
\text { Staf administrasi UKI melayani mahasiswa dengan ramah } \\
\text { Dosen UKI mampu menjelaskan materi kuliah dengan baik } \\
\text { Cara penyampaian materi kuliah di UKI menarik perhatian mahasiswa }\end{array}$ & $\begin{array}{l}3 \\
1 \\
1\end{array}$ & $\begin{array}{l}0 \\
0 \\
0\end{array}$ & $\begin{array}{c}14 \\
2 \\
0\end{array}$ & $\begin{array}{l}30 \\
17 \\
17\end{array}$ & $\begin{array}{l}30 \\
29 \\
27\end{array}$ & $\begin{array}{l}20 \\
47 \\
29\end{array}$ & $\begin{array}{l}6 \\
7 \\
9\end{array}$ \\
\hline $\begin{array}{l}13 \\
14 \\
15 \\
16 \\
17 \\
18\end{array}$ & $\begin{array}{l}\text { Dimensi Kehandalan/Realibility } \\
\text { Kehadiran dosen UKI dalam proses perkuliahan tepat waktu } \\
\text { Materi kuliah UKI sesuai dengan silabus } \\
\text { Materi kuliah UKI sesuai dengan jurusan yang diambil atau dipilih } \\
\text { Durasi/lama proses kuliah di UKI tepat waktu } \\
\text { Biaya kuliah UKI sesuai dengan manfaat perkuliahan } \\
\text { Nilai mata kuliah ditentukan secara tranparans }\end{array}$ & $\begin{array}{l}3 \\
1 \\
1 \\
2 \\
3 \\
5\end{array}$ & $\begin{array}{l}1 \\
0 \\
0 \\
0 \\
3 \\
1\end{array}$ & $\begin{array}{l}8 \\
1 \\
1 \\
3 \\
5 \\
1\end{array}$ & $\begin{array}{c}21 \\
8 \\
7 \\
17 \\
16 \\
15\end{array}$ & $\begin{array}{l}32 \\
25 \\
17 \\
38 \\
26 \\
19\end{array}$ & $\begin{array}{l}31 \\
64 \\
71 \\
38 \\
45 \\
55\end{array}$ & $\begin{array}{l}7 \\
4 \\
6 \\
5 \\
5 \\
7\end{array}$ \\
\hline & Dimensi Empati/Emphaty & & & & & & & \\
\hline 19 & Dosen UKI memberikan perhatian secara personal kepada mahasiswa & 2 & 0 & 6 & 34 & 30 & 29 & 2 \\
\hline 20 & $\begin{array}{l}\text { Dosen UKI bersedia berdiskusi dengan mahasiswa, baik di dalam maupun diluar } \\
\text { jam kuliah }\end{array}$ & 3 & 0 & 2 & 19 & 36 & 38 & 5 \\
\hline 21 & Petugas perpustakaan UKI melayani dengan ramah & 1 & 1 & 5 & 23 & 33 & 30 & 10 \\
\hline
\end{tabular}

Keterangan : $\mathrm{STS}=$ Sangat Tidak Setuju; TS $=$ Tidak Setuju; ATS $=$ Agak Tidak Setuju; $\mathrm{N}=$ Netral; AS $=$ Agak Setuju; $\mathrm{S}=$ Setuju; SS = Sangat Setuju.

Pada Tabel diatas terlihat bahwa sebagian besar responden menyatakan Agak Setuju (AS) dan Setuju (S) terhadap pernyataan kualitas layanan di UKI. Namun untuk satu pernyataan "Dosen UKI memberikan perhatian secara personal kepada mahasiswa" (dimensi empati), sebagian besar responden menyatakan netral. 


\section{Tingkat Kepentingan Responden terhadap Kualitas Layanan}

Selain harapan dan persepsi terhadap kinerja, responden juga memberikan penilaian mengenai tingkat kepentingan pernyataan kualitas layanan sebagaimana yang tersaji pada Tabel 5 berikut.

Tabel 5 Tingkat Kepentingan Responden terhadap Kualitas Layanan Suatu Universitas

\begin{tabular}{|c|c|c|c|c|c|c|c|c|}
\hline No & Pernyataan & STP & $\mathbf{T P}$ & ATP & $\mathbf{N}$ & AP & $\mathbf{P}$ & SP \\
\hline & Dimensi Bukti Fisik/Tangibles & & & & & & & \\
\hline 1 & Ruang kuliah nyaman dan tenang & 1 & 0 & 0 & 3 & 3 & 42 & 54 \\
\hline 2 & Lokasi kampus strategis/mudah dijangkau & 1 & 0 & 0 & 4 & 4 & 49 & 45 \\
\hline 3 & Universitas memiliki ketersediaan jurusan atau program studi & 2 & 0 & 0 & 3 & 2 & 54 & 42 \\
\hline 4 & Penampilan dosen selalu rapi & 1 & 0 & 0 & 6 & 8 & 67 & 21 \\
\hline 5 & $\begin{array}{l}\text { Fasilitas pendukung perkuliahan, seperti laboratorium, kantin, parkir, } \\
\text { tempat ibadah, dll }\end{array}$ & 1 & 0 & 0 & 1 & 4 & 36 & 61 \\
\hline \multirow[t]{2}{*}{6} & Fasilitas perpustakaan yang lengkap & 1 & 0 & 1 & 1 & 1 & 40 & 59 \\
\hline & Dimensi Daya Tanggap/Responsiveness & & & & & & & \\
\hline 7 & Pelayanan administrasi kepada mahasiswa dilakukan dengan cepat & 1 & 1 & 1 & 1 & 4 & 52 & 43 \\
\hline 8 & Proses perkuliahan berlangsung secara interaktif & 1 & 0 & 0 & 6 & 1 & 38 & 57 \\
\hline \multirow[t]{2}{*}{9} & Keluhan mengenai perkuliahan ditanggapi dengan baik & 1 & 0 & 1 & 3 & 2 & 36 & 60 \\
\hline & Dimensi Jaminan/Assurance & & & & & & & \\
\hline 10 & Staf administrasi melayani mahasiswa dengan ramah & 1 & 0 & 1 & 4 & 3 & 51 & 43 \\
\hline 11 & Dosen mampu menjelaskan materi kuliah dengan baik & 2 & 0 & 1 & 3 & 1 & 23 & 73 \\
\hline \multirow[t]{2}{*}{12} & Cara penyampaian materi kuliah menarik perhatian mahasiswa & 1 & 0 & 1 & 2 & 3 & 27 & 69 \\
\hline & Dimensi Kehandalan/Realibility & & & & & & & \\
\hline 13 & Kehadiran dosen dalam proses perkuliahan tepat waktu & 2 & 0 & 1 & 3 & 5 & 43 & 49 \\
\hline 14 & Materi kuliah sesuai dengan silabus & 1 & 0 & 0 & 5 & 5 & 38 & 54 \\
\hline 15 & Materi kuliah sesuai dengan jurusan yang diambil atau dipilih & 1 & 0 & 0 & 4 & 3 & 40 & 55 \\
\hline 16 & Durasi/lama proses kuliah tepat waktu & 2 & 0 & 1 & 2 & 6 & 49 & 43 \\
\hline 17 & Biaya kuliah sesuai dengan manfaat perkuliahan & 1 & 0 & 0 & 4 & 3 & 31 & 64 \\
\hline \multirow[t]{2}{*}{18} & Nilai mata kuliah ditentukan secara tranparans & 1 & 0 & 1 & 3 & 2 & 31 & 65 \\
\hline & Dimensi Empati/Emphaty & & & & & & & \\
\hline 19 & Dosen memberikan perhatian secara personal kepada mahasiswa & 2 & 0 & 2 & 11 & 16 & 34 & 38 \\
\hline 20 & $\begin{array}{l}\text { Dosen bersedia berdiskusi dengan mahasiswa, baik di dalam maupun diluar } \\
\text { jam kuliah }\end{array}$ & 1 & 0 & 1 & 5 & 7 & 38 & 51 \\
\hline 21 & Petugas perpustakaan melayani dengan ramah & 0 & 1 & 0 & 2 & 1 & 53 & 46 \\
\hline
\end{tabular}

Keterangan : $\mathrm{STP}=$ Sangat Tidak Penting; $\mathrm{TP}=$ Tidak Penting; $\mathrm{ATP}=$ Agak Tidak Penting; $\mathrm{N}=\mathrm{Netral} ; \mathrm{AP}=$ Agak Penting; $\mathrm{P}=$ Penting; $\mathrm{SP}=$ Sangat Penting.

Berdasarkan Tabel di atas, terlihat bahwa sebagian besar responden menilai Penting (P) dan Sangat Penting (SP) terhadap pernyataan kualitas layanan suatu universitas.

\section{Analisis Servqual}

Analisis servqual merupakan selisih antara layanan UKI yang dirasakan atau dipersepsikan oleh mahasiswa dengan harapan mahasiswa terhadap layanan UKI. Perhitungan servqual ini sering kali disebut sebagai gap (kesenjangan). Tiap responden menilai persepsi terhadap kinerja dan harapan terhadap atribut kualitas layanan di UKI. 
Tabel 6 Analisis Servqual Kualitas Layanan Universitas Kristen Indonesia

\begin{tabular}{|c|c|c|c|c|}
\hline No & Pernyataan & Persepsi & Harapan & Gap \\
\hline & Dimensi Bukti Fisik/Tangibles & & & $-0,86$ \\
\hline 1 & Ruang kuliah nyaman dan tenang & 5,37 & 6,51 & $-1,15$ \\
\hline 2 & Lokasi kampus strategis/mudah dijangkau & 5,79 & 6,37 & $-0,58$ \\
\hline 3 & Universitas memiliki ketersediaan jurusan atau program studi & 5,37 & 6,20 & $-0,83$ \\
\hline 4 & Penampilan dosen selalu rapi & 5,50 & 6,07 & $-0,57$ \\
\hline 5 & $\begin{array}{l}\text { Fasilitas pendukung perkuliahan, seperti laboratorium, kantin, parkir, tempat } \\
\text { ibadah, dll }\end{array}$ & 5,44 & 6,36 & $-0,92$ \\
\hline \multirow[t]{2}{*}{6} & Fasilitas perpustakaan yang lengkap & 5,18 & 6,28 & $-1,10$ \\
\hline & Dimensi Daya Tanggap/Responsiveness & & & $-1,34$ \\
\hline 7 & Pelayanan administrasi kepada mahasiswa dilakukan dengan cepat & 4,64 & 6,18 & $-1,54$ \\
\hline 8 & Proses perkuliahan berlangsung secara interaktif & 5,17 & 6,22 & $-1,06$ \\
\hline \multirow[t]{2}{*}{9} & Keluhan mengenai perkuliahan ditanggapi dengan baik & 4,86 & 6,29 & $-1,43$ \\
\hline & Dimensi Jaminan/Assurance & & & $-1,15$ \\
\hline 10 & Staf administrasi melayani mahasiswa dengan ramah & 4,66 & 6,02 & $-1,36$ \\
\hline 11 & Dosen mampu menjelaskan materi kuliah dengan baik & 5,35 & 6,45 & $-1,10$ \\
\hline \multirow[t]{2}{*}{12} & Cara penyampaian materi kuliah menarik perhatian mahasiswa & 5,45 & 6,44 & $-0,99$ \\
\hline & Dimensi Kehandalan/Realibility & & & $-0,83$ \\
\hline 13 & Kehadiran dosen dalam proses perkuliahan tepat waktu & 4,93 & 6,16 & $-1,22$ \\
\hline 14 & Materi kuliah sesuai dengan silabus & 5,56 & 5,95 & $-0,39$ \\
\hline 15 & Materi kuliah sesuai dengan jurusan yang diambil atau dipilih & 5,68 & 6,13 & $-0,45$ \\
\hline 16 & Durasi/lama proses kuliah tepat waktu & 5,17 & 5,90 & $-0,74$ \\
\hline 17 & Biaya kuliah sesuai dengan manfaat perkuliahan & 5,08 & 6,31 & $-1,23$ \\
\hline \multirow[t]{2}{*}{18} & Nilai mata kuliah ditentukan secara tranparans & 5,28 & 6,26 & $-0,98$ \\
\hline & Dimensi Empati/Empathy & & & $-0,92$ \\
\hline 19 & Dosen memberikan perhatian secara personal kepada mahasiswa & 4,80 & 5,48 & $-0,68$ \\
\hline 20 & $\begin{array}{l}\text { Dosen bersedia berdiskusi dengan mahasiswa, baik di dalam maupun diluar jam } \\
\text { kuliah }\end{array}$ & 5,13 & 6,12 & $-0,99$ \\
\hline 21 & Petugas perpustakaan melayani dengan ramah & 5,10 & 6,18 & $-1,09$ \\
\hline
\end{tabular}

Berdasarkan analisis servqual pada Tabel 6, terlihat bahwa semua atribut memiliki gap bernilai negatif. Nilai gap terbesar adalah untuk pernyataan "pelayanan administrasi dilakukan dengan cepat" dengan nilai gap $-1,54$, "keluhan mengenai perkuliahan ditanggapi dengan baik" dengan nilai gap $-1,43$. Sebaliknya untuk nilai gap terkecil "materi kuliah sesuai dengan silabus" dengan gap $-0,39$ dan "materi kuliah sesuai dengan jurusan yang diambil atau dipilih" dan nilai gap -0,45. Berdasarkan dimensinya, gap terbesar hingga gap terkecil secara berurutan adalah sebagai berikut dimensi daya tanggap/responsiveness yaitu sebesar -1,34; dimensi jaminan/assurance sebesar -1,15; dimensi empati dengan nilai gap - 0,92 ; dimensi bukti fisik/tangible sebesar $-0,85$; serta dimensi kehandalan/realibility sebesar $-0,83$. Hal tersebut mengindikasikan bahwa kinerja dimensi daya tanggap masih belum harapan responden dalam hal kecepatan pelayanan administrasi dan keluhan perkuliahan belum ditanggapi dengan baik.

\section{Importance-Performance Analysis}

Pada analisis IPA, tiap responden selain memberikan penilaian terhadap persepsi kinerja atribut layanan, juga dinilai tingkat kepentingan atribut tersebut. Adapun nilai rata-rata kepentingan dan persepsi kinerja tiap pernyataan tersaji pada Tabel 7 berikut. 
Tabel 7 Tingkat Kepentingan Dan Persepsi Kinerja Kualitas Layanan

\begin{tabular}{|c|c|c|c|}
\hline No & Pernyataan & Kepentingan & Persepsi \\
\hline & Dimensi Bukti Fisik/Tangibles & & \\
\hline 1 & Ruang kuliah nyaman dan tenang & 6,39 & 5,37 \\
\hline 2 & Lokasi kampus strategis/mudah dijangkau & 6,27 & 5,79 \\
\hline 3 & Universitas memiliki ketersediaan jurusan atau program studi & 6,23 & 5,37 \\
\hline 4 & Penampilan dosen selalu rapi & 5,96 & 5,50 \\
\hline 5 & Fasilitas pendukung perkuliahan, seperti laboratorium, kantin, parkir, tempat ibadah, dll & 6,49 & 5,44 \\
\hline 6 & Fasilitas perpustakaan yang lengkap & 6,47 & 5,18 \\
\hline $\begin{array}{l}7 \\
8 \\
9\end{array}$ & $\begin{array}{l}\text { Dimensi Daya Tanggap/Responsiveness } \\
\text { Pelayanan administrasi kepada mahasiswa dilakukan dengan cepat } \\
\text { Proses perkuliahan berlangsung secara interaktif } \\
\text { Keluhan mengenai perkuliahan ditanggapi dengan baik }\end{array}$ & $\begin{array}{l}6,24 \\
6,38 \\
6,43\end{array}$ & $\begin{array}{l}4,64 \\
5,17 \\
4,86\end{array}$ \\
\hline $\begin{array}{l}10 \\
11 \\
12\end{array}$ & $\begin{array}{l}\text { Dimensi Jaminan/Assurance } \\
\text { Staf administrasi melayani mahasiswa dengan ramah } \\
\text { Dosen mampu menjelaskan materi kuliah dengan baik } \\
\text { Cara penyampaian materi kuliah menarik perhatian mahasiswa }\end{array}$ & $\begin{array}{l}6,23 \\
6,51 \\
6,52\end{array}$ & $\begin{array}{l}4,66 \\
5,35 \\
5,45\end{array}$ \\
\hline $\begin{array}{l}13 \\
14 \\
15 \\
16 \\
17 \\
18\end{array}$ & $\begin{array}{l}\text { Dimensi Kehandalan/Realibility } \\
\text { Kehadiran dosen dalam proses perkuliahan tepat waktu } \\
\text { Materi kuliah sesuai dengan silabus } \\
\text { Materi kuliah sesuai dengan jurusan yang diambil atau dipilih } \\
\text { Durasi/lama proses kuliah tepat waktu } \\
\text { Biaya kuliah sesuai dengan manfaat perkuliahan } \\
\text { Nilai mata kuliah ditentukan secara tranparans }\end{array}$ & $\begin{array}{l}6,24 \\
6,33 \\
6,38 \\
6,19 \\
6,47 \\
6,48\end{array}$ & $\begin{array}{l}4,93 \\
5,56 \\
5,68 \\
5,17 \\
5,08 \\
5,28\end{array}$ \\
\hline & Dimensi Empati/Empathy & & \\
\hline $\begin{array}{l}19 \\
20\end{array}$ & $\begin{array}{l}\text { Dosen memberikan perhatian secara personal kepada mahasiswa } \\
\text { Dosen bersedia berdiskusi dengan mahasiswa, baik di dalam maupun diluar jam kuliah }\end{array}$ & $\begin{array}{l}5,84 \\
6,25\end{array}$ & $\begin{array}{l}4,80 \\
5,13\end{array}$ \\
\hline 21 & $\begin{array}{l}\text { Petugas perpustakaan melayani dengan ramah } \\
\text { Rata-rata }\end{array}$ & $\begin{array}{l}6,36 \\
6,32\end{array}$ & $\begin{array}{l}5,10 \\
5,21\end{array}$ \\
\hline
\end{tabular}

Nilai tingkat kepentingan dan persepsi terhadap kinerja layanan pada Tabel 7 digunakan dalam menentukan koordinat dalam Matriks IPA pada Gambar 3. Selanjutnya hasil rataan penilaian persepsi kinerja (performance) dan tingkat kepentingan (importance) diplot pada Diagram Kartesius sebagai titik perpotongan yang membagi menjadi empat kuadran. Sebagai sumbu mendatar (X) adalah persepsi kinerja atribut dan sumbu vertikalnya (Y) yaitu tingkat kepentingan atribut.

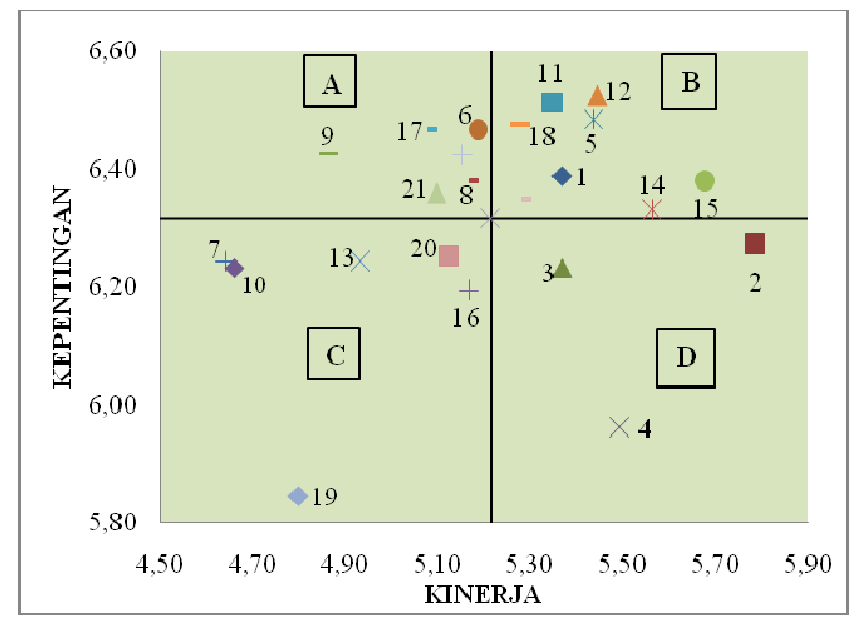

Gambar 3 IPA Kualitas Layanan UKI 
Nomor atribut pada Gambar 3 diatas sama dengan no pernyataan pada Tabel 7. Hasil analisis IPA, pernyataan/atribut kualitas layanan yang berada dalam empat kuadran yang berbeda yang dapat dijelaskan sebagai berikut.

\section{Kuadran A}

Atribut yang berada dalam kuadran A dinilai penting oleh responden, namun UKI perlu untuk meningkatkan kinerja atribut tersebut. Atribut-atribut layanan yang perlu ditingkatkan kinerjanya secara optimal adalah:

- fasilitas perpustakaan yang lengkap (dimensi bukti fisik),

- proses kuliah berlangsung interaktif (dimensi daya tanggap),

- $\quad$ keluhan mengenai perkuliahan ditanggapi dengan baik (dimensi daya tanggap)

- biaya kuliah sesuai dengan manfaat perkuliahan (dimensi kehandalan),

- petugas perpustakaan melayani dengan ramah (dimensi empati).

\section{Kuadran B}

Kuadran B terdiri dari atribut yang tingkat kepentingan tinggi dengan kinerja atribut telah memenuhi keinginan responden. Dengan demikian kinerja atribut yang berada di kuadran B perlu untuk dipertahankan kinerjanya oleh pihak UKI. Adapun atribut- atribut yang termasuk di Kuadran B, yaitu:

- ruang kuliah nyaman dan tenang (dimensi bukti fisik),

- fasilitas pendukung perkuliahan, seperti laboratorium, kantin, parkir, tempat ibadah, dll (dimensi bukti fisik),

- dosen mampu menjelaskan materi kuliah dengan baik (dimensi jaminan),

- cara penyampaian materi kuliah menarik perhatian mahasiswa (dimensi jaminan),

- materi kuliah sesuai dengan silabus (dimensi kehandalan),

- materi kuliah sesuai dengan jurusan yang diambil atau dipilih (dimensi kehandalan),

- nilai mata kuliah ditentukan secara tranparans (dimensi kehandalan).

\section{Kuadran C}

Atribut pada kuadran $\mathrm{C}$ dianggap kurang penting oleh mahasiswa dengan kinerja yang cukup atau biasa saja. Atribut yang temasuk dalam kuadran ini adalah:

- pelayanan administrasi kepada mahasiswa dilakukan yang cepat (dimensi daya tanggap),

- staf administrasi melayani mahasiswa dengan ramah (dimensi jaminan),

- kehadiran dosen dalam proses perkuliahan tepat waktu (dimensi kehandalan),

- durasi/lama proses kuliah tepat waktu (dimensi kehandalan),

- dosen memberikan perhatian secara personal kepada mahasiswa (dimensi empati),

- dosen bersedia berdiskusi dengan mahasiswa, baik di dalam maupun diluar jam kuliah (dimensi empati).

\section{Kuadran D}

Kuadran D terdiri dari atribut yang dinilai kurang penting bagi mahasiswa tetapi kinerjanya dilakukan oleh pihak UKI dengan sangat baik bahkan berlebihan. Atribut yang tergolong dalam kuadran ini adalah sebagai berikut:

- lokasi kampus strategis atau mudah dijangkau (dimensi bukti fisik),

- universitas memiliki ketersediaan jurusan atau program studi (dimensi bukti fisik),

- penampilan dosen selalu rapi (dimensi bukti fisik). 


\section{SIMPULAN}

Berdasarkan hasil penelitian maka dapat disimpulkan sebagai berikut. Semua kinerja atribut layanan yang diselenggarakan oleh UKI belum memenuhi harapan mahasiswa yang diindikasikan dengan nilai gap yang negatif. Nilai gap terbesar adalah untuk atribut pelayanan administrasi dilakukan dengan cepat dan atribut keluhan mengenai perkuliahan ditanggapi dengan baik. Adapun nilai gap terkecil untuk atribut materi kuliah sesuai dengan silabus dan atribut materi kuliah sesuai dengan jurusan yang diambil atau dipilih. Berdasarkan analisis IPA terlihat bahwa atribut menjadi prioritas ditingkatkan kinerjanya yaitu atribut fasilitas perpustakaan lebih lengkap, proses kuliah berlangsung interaktif, keluhan mengenai perkuliahan ditanggapi dengan baik, biaya kuliah sesuai dengan manfaat perkuliahan, serta petugas perpustakaan melayani dengan ramah. Adapun atributatribut layanan yang harus dipertahankan kinerjanya oleh UKI adalah ruang kuliah nyaman dan tenang, fasilitas pendukung perkuliahan (laboratorium, kantin, parkir, tempat ibadah, dll), dosen mampu menjelaskan materi kuliah dengan baik, cara penyampaian materi kuliah menarik perhatian mahasiswa, materi kuliah sesuai dengan silabus, materi kuliah sesuai dengan jurusan yang diambil atau dipilih, dan nilai mata kuliah ditentukan secara tranparan. Meskipun terdapat atribut yang kepentingannya rendah dengan kinerjanya cukup (berdasarkan hasil analisis IPA), namun tetap harus ditingkatkan kinerjanya mengingat semua atribut layanan belum memenuhi harapan mahasiswa (berdasarkan analisis gap). Atribut tersebut di antaranya atribut pelayanan administrasi kepada mahasiswa dilakukan yang cepat, staf administrasi melayani mahasiswa dengan ramah, kehadiran dosen dalam proses perkuliahan tepat waktu, durasi/lama proses kuliah tepat waktu, dan dosen bersedia berdiskusi dengan mahasiswa baik di dalam maupun diluar jam kuliah.Terdapat tiga atribut dalam dimensi bukti fisik kualitas layanan UKI yang kinerjanya dinilai sangat baik meskipun tingkat kepentingan terhadap ketiga atribut tersebut rendah. Ketiga atribut tersebut adalah lokasi kampus strategis atau mudah dijangkau, UKI memiliki ketersediaan jurusan atau program studi dan penampilan dosen selalu rapi. Sebagai penyelenggara pendidikan, UKI perlu untuk meningkatkan kinerja atribut layanannya dalam rangka memenuhi harapan mahasiswa. Namun, atribut yang menjadi prioritas perbaikan kinerja layanan UKI adalah sebagai berikut: fasilitas perpustakaan untuk lebih diperlengkap, proses perkuliahan berlangsung secara interaktif, adanya tanggapan terhadap keluhan mengenai perkuliahan, biaya kuliah lebih disesuaikan dengan manfaat perkuliahan, serta petugas perpustakaan melayani dengan ramah.

\section{DAFTAR PUSTAKA}

Damajanti, D. (2006). Pengukuran Kualitas Pelayanan di Apotik Trijaya. Telaah Manajemen, 1 (2): 1 $-24$.

Furqon, C. (2007). Kualitas Pelayanan pada Perguruan Tinggi. Jurnal Ilmu Administrasi, 4 (4): 372379.

Kotler, P., and Keller, K. L. (2012). Marketing Management. 14th Edition. New Jersey: Prentice Hall.

Muluk, A. (2008). Analisis Kualitas Pelayanan Jasa Perbankan (Studi Kasus : PT. Bank Negara Indonesia (Persero) Tbk Cabang Padang). Jurnal Ilmiah Teknik Industri. Optimasi Sistem Industri, $8(1): 22-31$.

Mullins, J. W., and Jr, O. C. W. (2010). Marketing Management: A Strategic Decision-Making Approach. Seventh Edition. New York: McGraw Hill International. 
Sekaran, U. (2006). Metodologi Penelitian untuk Bisnis. Edisi keempat. Jakarta: Salemba Empat.

Sugiyono. (2002). Statistika Untuk Penelitian. Bandung: CV Alfabeta.

Tjiptono, F. (2006). Pemasaran Jasa. Edisi Pertama. Malang: Bayu Publishing.

Tjiptono, F., dan Chandra, G. (2011). Service Quality and Satisfaction. Edisi 3. Yogyakarta: Penerbit Andi.

Zeithaml, V.A., Bitner, M. J., and Gremler, D. A. (2008). Services Marketing: Integrating Customer. Focus Across the Firm. Fifth Edition. New York: McGraw Hill.

http://www.uki.ac.id/concrete5411/index.php/tentang-kami/ Sejarah Singkat Berdirinya Universitas Kristen Indonesia. Diakses tanggal 2 Juni 2012 